Available online at https://jurnal.stmikroyal.ac.id/index.php/jurdimas

\title{
PEMANFAATAN APLIKASI E-MASJID SEBAGAI INFORMASI BAGI BKM AL-IKHLAS
}

\author{
Nasrun Marpaung ${ }^{1 *}$, Andri Nata ${ }^{2}$, Rolly Yesputra ${ }^{3}$ \\ ${ }^{1}$ Sistem Informasi, Sekolah Tinggi Manajemen Informatika dan Komputer Royal \\ ${ }^{2}$ Manajemen Informatika, Sekolah Tinggi Manajemen Informatika dan Komputer Royal \\ ${ }^{3}$ Sistem Komputer, Sekolah Tinggi Manajemen Informatika dan Komputer Royal \\ email: *nasrunavara@gmail.com
}

\begin{abstract}
All fields of work have utilized information technology because data processing is fast and produces good results as expected. Utilization of Information Systems as a form of transparency of the Al-Ikhlas mosque in improving the quality of BKM performance by utilizing the website as a medium of information is a form of concern and a form of good performance so that later the Kisaran Naga village community can access the latest information. In addition, BKM Al-Ikhlas annually receives zakat as one of the routine activities that really requires the latest and greatest data, so that there are no accurate errors in delivering zakat to the mustahaq. However, because there is no system that can accommodate this data, it becomes a problem every year. So we need an application that can provide solutions to existing problems. This application is made using the PHP programming language which produces applications that can be accessed from anywhere and anytime, making it easier for users. The E-Masjid application is also an application that can manage mosque cash information, and zakat payments that make it easier for the community of the Kisaran Naga village and BKM Al-Ikhlas to handle good zakat transactions.
\end{abstract}

Keywords: application; e-masjid; zakat

\begin{abstract}
Abstrak: Seluruh bidang pekerjaan sudah memanfaatkan teknologi informasi dikarenakan pengolahan data yang cepat dan baik menghasilkan hasil yang baik juga sesuai dengan yang diharapkan. Pemanfaatan Sistem Informasi sebagai bentuk transparansi kegiatan masjid Al-Ikhlas dalam peningkatan kualitas kinerja BKM dengan memanfaatkan website sebagai media informasi merupakan bentuk kepedulian dan bentuk kinerja yang baik yang nantinya pihak masyarakat kelurahan Kisaran Naga dapat mengakses informasi yang up to date. Selain itu BKM Al-Ikhlas setiap tahunnya melakukan penerimaan zakat sebagai salah satu kegiatan rutin yang sangat membutuhkan data yang akurat dan mutakhir, sehingga tidak ada kesalahan dalam penyaluran zakat kepada yang mustahaq. Namun dikarenakan tidak adanya sistem yang dapat menampung data tersebut menjadi masalah setiap tahunnya. Sehingga dibutuhkan sebuah aplikasi yang dapat memberikan solusi terhadap permasalahan yang ada. Aplikasi ini dibuat menggunakan bahasa pemrograman PHP yang menghasilkan aplikasi yang dapat diakses dari manapun dan kapanpun sehingga memudahkan pengguna. Aplikasi E-Masjid juga merupakan aplikasi yang dapat mengelola informasi kas masjid, dan pembayaran zakat yang memudahkan masyarakat lingkungan kelurahan Kisaran Naga dan BKM Al-Ikhlas dalam mengelola transaksi zakat yang baik.
\end{abstract}

Kata kunci: aplikasi; e-masjid; zakat 
Available online at https://jurnal.stmikroyal.ac.id/index.php/jurdimas

\section{PENDAHULUAN}

Teknologi informasi dan komunikasi yang bekembang dengan pesat tentunya sangat membantu disetiap pekerjaan manusia. Setiap manusia ingin setiap pekerjaan dapat diselesaikan dengan cepat dan tepat serta dengan hasil yang baik. Seluruh bidang pekerjaan sudah memanfaatkan teknologi informasi dikarenakan pengolahan data yang cepat dan baik menghasilkan hasil yang baik juga sesuai dengan yang diharapkan. Tidak hanya pada instansi dan lembaga, pada organisasi masyarakat juga dapat merasakan kemajuan teknologi tersebut.

Terkait pengolahan data tentunya tidak terlepas dari sistem informasi yang dapat menyajikan data yang diinginkan, baik bagi instansi, lembaga maupun organisasi. Masjid meruapakan tempat beribadah kepada Allah sebagai sarana atau tempat mengabdi kepada Allah.

Pada saat hijrah dari Mekah ke Madinah yang ditemani Abu Bakar, Rasulullah shallallahu 'alaihi wa sallam melewati daerah Quba, di sana beliau mendirikan Masjid pertama sejak masa kenabiannya, yaitu Masjid Quba (QS 9:108, At Taubah). Rasulullah juga pernah mendirikan masjid setelah di Madinah, yang merupakan tempat melaksanaan shalat berjamaah oleh umat Islam dan melaksanakan aktivitas sosial lainnya. Pada perkembangannya disebut dengan Masjid Nabawi (Anam, Khambali, \& Wicaksono, 2019).

Masjid Al-Ikhlas juga merupakan organisasi keagamaan yang membutuhkan pengolahan data yang lebih baik oleh BKM Al-Ikhlas itu sendiri. Pemanfaatan Sistem Informasi sebagai bentuk transparansi kegiatan masjid AlIkhlas dalam peningkatan kualitas kinerja BKM dalam era modern tentunya membutuhkan media informasi seperti website untuk menyediakan informasi yang up to date sebagai bentuk kepedulian dan bentuk kinerja yang baik yang dapat diakses oleh masyarakat sekitar kelurahan Kisaran Naga. Pengelolaan data pada masjid Al-Ikhlas merupakan kegiatan yang paling banyak dilakukan sebagai bentuk pelayanan terhadap masyarakat. Kegiatan yang dilakukan berupa memberikan informasi pengelolaan kas, jadwal kajian dan pelaksanaan zakat. (Amarudin \& Sofiandri, 2018)

Zakat adalah perintah Allah yang wajib dilakukan oleh umat Islam yang terdapat pada Al-Qur'an (Bahri \& Oktaviani, 2019). Hal ini sebagaimana firman Allah dalam QS: at-Taubah ayat 103, "Ambillah zakat dari sebagian harta mereka, dengan zakat itu kamu membersihkan dan mensucikan mereka". Dalam undang-undang nomor 23 Tahun 2011 pasal 1 dan pasal 2 juga dijelaskan tentang zakat yang merupakan harta yang wajib bagi seorang muslim untuk dikeluarkan bahkan bagi badan usaha untuk diberikan kepada yang berhak menerimanya sesuai dengan syariat islam (Bahri \& Arif, 2020);(Novansyah, Sunardi, \& Ramadhan, 2015).

Pelaksanaan zakat merupakan kegiatan rutin yang dilakukan oleh pihak BKM Al-Ikhlas pada tiap tahunnya sebagai rukun islam yang wajib dilaksanakan oleh masyarakat muslim disekitar lingkungan kelurahan Kisaran Naga. Namun dengan banyaknya data yang harus dikelola membuat pihak BKM juga kesulitan dikarenakan data yang tidak baku. Semua kegiatan BKM dikelola secara konvensional sehingga memungkinkan adanya kesalahan disetiap kegiatan. Berdasarkan kegiatan yang diikuti peneliti, ditemukan data penerima zakat tahun sebelumnya tidak tersimpan dengan baik. Jenis beras dan harga yang masih ragu dalam merujuk 
pada harga yang lama, dan data administrasi lainnya yang tidak tersimpan dengan baik. Selain itu penyampaian informasi yang kurang tepat dan cepat juga menjadi kendala.

Untuk itu diperlukan aplikasi yang dapat memberikan solusi terhadap permasalahan tersebut yaitu Aplikasi EMasjid yang merupakan aplikasi pengelola informasi kas masjid, dan pembayaran zakat yang memudahkan masyarakat lingkungan kelurahan Kisaran Naga dan BKM Al-Ikhlas dalam mengelola transaksi zakat yang baik.

\section{METODE}

Untuk menghasilkan penelitian yang baik sesuai dengan yang diinginkan dari permasalahan-permasalahan yang ada, maka peniliti melakukan beberapa metode seperti terjun langsung ikut serta dalam kegiatan penerimaan dan penyaluran zakat hingga selesai. Pelaksanaan zakat dilakukan dilingkungan Masjid Al-Ikhlas pada 20 ramadhan hingga selesai. (Bastiar \& Bahri, 2019)

Dari kegiatan peneliti menganalisa setiap kendala dengan terus memberikan solusi sementara untuk mengatasi kendala kendala yang ditemukan. Dari kegiatan transaksi zakat juga ditemukan beberapa kendala sehingga diperoleh fitur apa yang harus ditambahkan pada aplikasi yang akan dibuat.

Maka metode ini termasuk metode observasi yang digunakan. Dan dalam pengembangan sistem informasi E-Masjid digunakan metode waterfall. Karena metode ini merupakan metode yang melakukan pendekatan langsung secara sistematis dan berurutan dalam membangun sebuah sistem. Sehingga menghasilkan sistem dengan kualitas baik. (Elsera \& Zakir, 2021).

Setelah mengikuti kegiatan zakat dan kas masjid selama 3 hari maka dilakukan perancangan aplikasi dan perancangan database.

\section{PEMBAHASAN}

\section{Pembuatan Aplikasi E-Masjid}

Setelah melakukan analisa terkait transaksi zakat dan proses pengelolaan kas masjid secara langsung ikut melaksanakan kegiatan tersebut. Maka peneliti merancang dan membuat aplikasi E-Masjid sesuai hasil analisa yang diperoleh dengan merancang database dan desain perancangan aplikasi. Aplikasi yang dibuat berbasis localhost yang dibuat dengan bahasa pemrograman PHP dan database MySQL. Sampai dengan aplikasi selesai dan dapat dijalankan dan secara online dapat diakses sebagai bentuk implementasi. Dengan bahasa pemrograman PHP dan editor sublime text 3 sebagai editor membantu menyelesaikan proses perancangan pengkodean dengan baik.

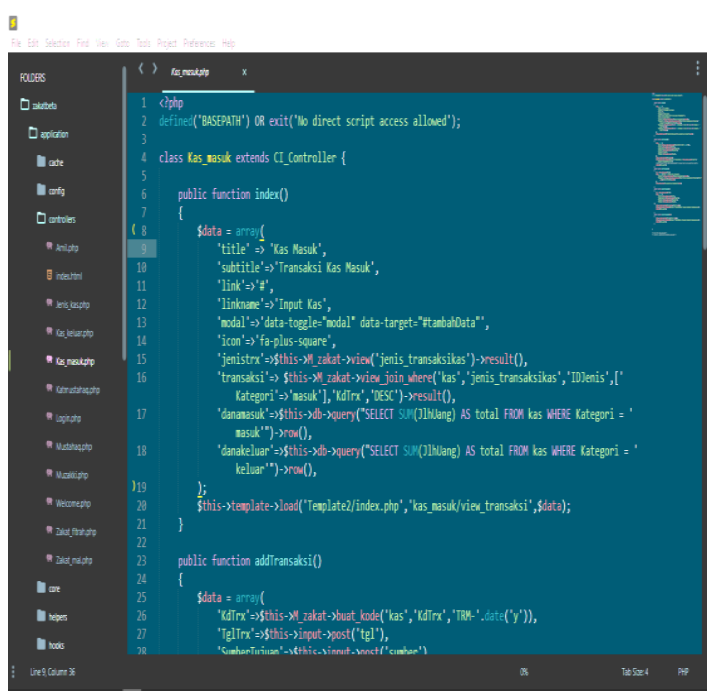

Gambar 1. Editor Sublime Text 3 


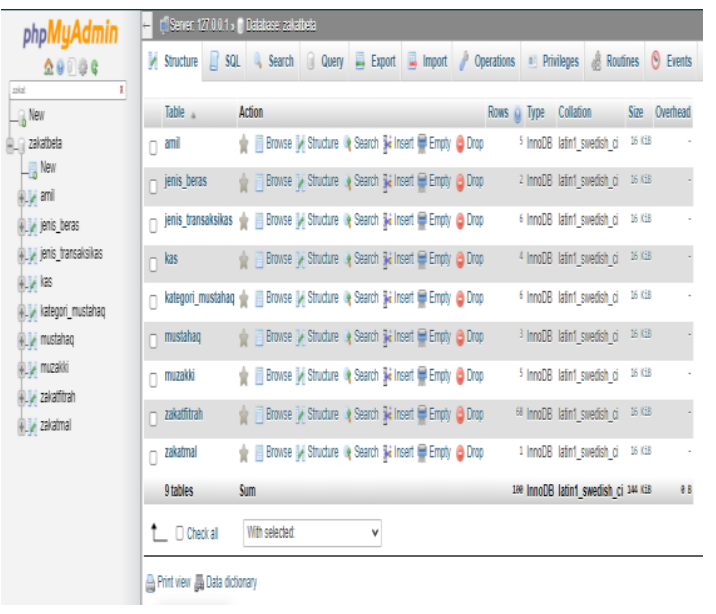

Gambar 2. Database

\section{Pelatihan Penggunaan Aplikasi}

Pada tahap ini dilakukan pelatihan kepada anggota BKM terhadap penggunaan aplikasi E-Masjid. Pelatihan dilaksanakan selama dua hari, dan dilaksanakan secara ongoing hingga selesai pelaksanaan kegiatan zakat. Pada saat pelatihan anggota BKM juga sangat antusias dalam belajar menggunakan aplikasi dan didampingi langsung oleh tim pengabdian. Pada saat proses penerimaan zakat berlangsung setiap transaksinya langsung diproses menggunakan aplikasi e-masjid yang sudah dibuat. Selain itu para tim PkM juga mendemokan bagaimana cara menambahkan data transaksi kas masuk dan kas keluar pada bendahara BKM dengan sangat baik hingga bendahara maksimal dalam proses input data kas keluar dan kas masuk.

Dengan adanya pemberian informasi keuangan yang bersifat terbuka dan jujur kepada masyarakat itu sudah termasuk dalam bentuk transparansi dikarenakan masyarakat juga memiliki hak untuk mengetahui secara terbuka dan menyeluruh atas pertanggung jawaban pengelola keuangan dalam pengelolaan sumber daya yang dipercayakan kepadanya dan ketaannya pada aturan yang telah disepakati bersama. Sehingga bentuk pertanggung jawaban oleh pengelola dalam mengelola sumber daya termasuk keuangan serta pelaksanaan kebijkan merupakan sebuah akuntabilitas dalam mencapai tujuan yang telah ditetapkan secara priodik. (Bulaeng, Bakri, \& Sidin, 2019).

Untuk melakukan penambahan data transaksi zakat maka petugas memilih menu transaksi zakat dan zakat fitrah dan kemudian menekan tombol bayar zakat. Seperti pada gambar 4 . Begitu juga pada proses menambah data kas masuk dan keluar, petugas BKM memilih menu kelola uang kas, uang masuk dan input uang kas.

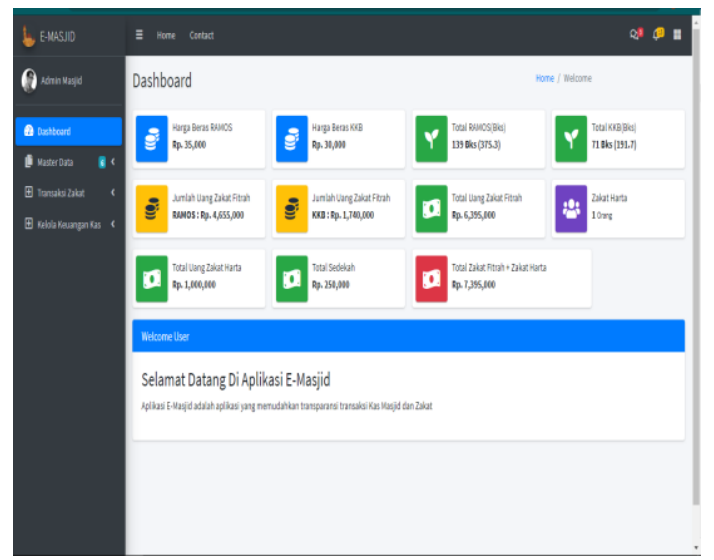

Gambar 3. Tampilan Beranda Aplikasi EMasjid

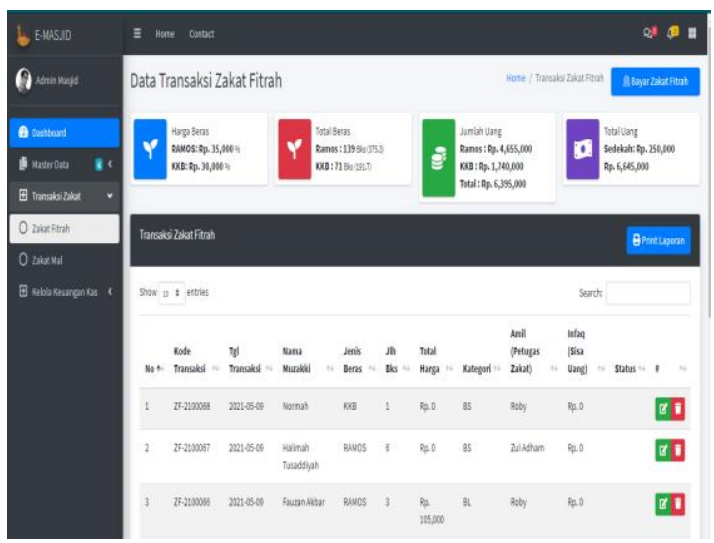

Gambar 4. Menu Transaksi Zakat 


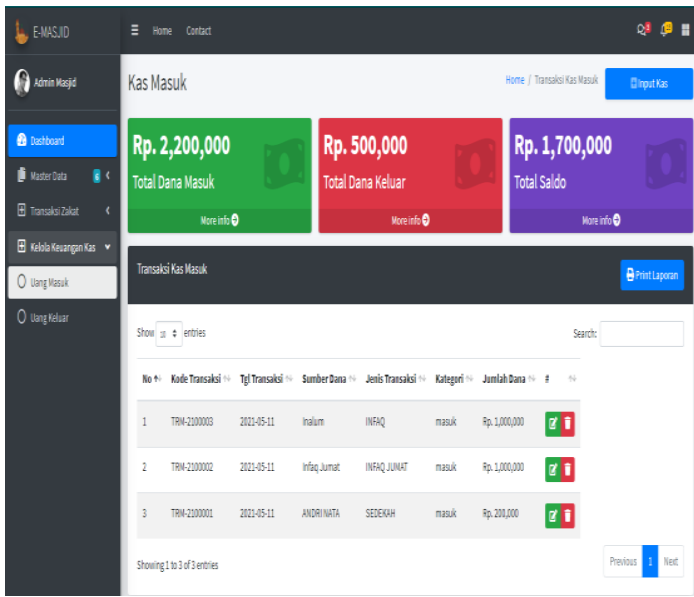

Gambar 5. Menu Transaksi Uang Kas

\section{SIMPULAN}

Berdasarkan kegiatan pelatihan yang sudah dilakukan di Masjid AlIkhlas dengan memanfaatkan aplikasi EMasjid, pihak BKM dapat memenuhi kemauan masyarakat sebagai bentuk transaparansi kinerja dengan adanya laporan kas keluar dan kas masuk yang up to date yang disajikan dengan aplikasi yang langsung dapat dilihat oleh masyarakat. Selain itu transaksi zakat yang dilakukan juga cepat dan tepat waktu dan data penerima zakat juga dapat dilihat langsung sehigga tidak menjadi kecemburuan sosial dan kecurigaan masyarakat terhadap penerima zakat dan panitia zakat maupun BKM Al-Ihlas itu sendiri.

\section{UCAPAN TERIMA KASIH}

Ucapan terima kasih kepada BKM Masjid Al-Ikhlas yang telah banyak membantu dalam memberikan ruang gerak yang sangat kekeluargaan sehingga menghasilkan aplikasi yang sesuai dengan kebutuhan BKM. Ucapan terima kasih yang sama juga kepada LPPM
STMIK Royal atas bantuan, dukungan dan kerja samanya sehingga kegiatan PKM ini dapat terlaksana dengan baik.

\section{DAFTAR PUSTAKA}

Amarudin, A., \& Sofiandri, A. (2018). Perancangan dan Implementasi Aplikasi Ikhtisar Kas Masjid Istiqomah Berbasis Desktop. Jurnal Tekno Kompak, 12(2), 51. doi: 10.33365/jtk.v12i2.148

Anam, A., Khambali, A., \& Wicaksono, T. A. (2019). Sistem Informasi Manajemen Masjid Di Kecamatan Kajen Berbasis Android. ...: Membangun Informasi Dan ..., (1), 35-43.

Bahri, E. S., \& Arif, Z. (2020). Analisis Efektivitas Penyaluran Zakat pada Rumah Zakat. Al Maal: Journal of Islamic Economics and Banking, 2(1), 13. doi: 10.31000/almaal.v2i1.2642

Bahri, E. S., \& Oktaviani, R. (2019). Zakat Produktif Sebagai Modal Kerja Usaha Mikro. Perisai: Islamic Banking and Finance Journal, 2(2), 101. doi: 10.21070/perisai.v2i2.1686

Bastiar, Y., \& Bahri, E. S. (2019). Model Pengkuran Kinerja Lembaga Zakat di Indonesia. ZISWAF: Jurnal Zakat Dan Wakaf, 6(1), 43. doi: 10.21043/ziswaf.v1i1.5609

Bulaeng, A. M., Bakri, H., \& Sidin, U. S. (2019). Pengembangan System Informasi Keuangan Masjid Babul Muttaqien Parang Tambung Kota Makassar. Jurnal MediaTIK, 1(1), 54-61.

Elsera, M., \& Zakir, A. (2021). Sistem Informasi E-Smart Application Masjid Berbasis Web. 
Jurdimas (Jurnal Pengabdian Kepada Masyarakat) Royal

Vol. 4 No. 3, September 2021, hlm. 301 - 306

Available online at https://jurnal.stmikroyal.ac.id/index.php/jurdimas

Jurnal.Uisu.Ac.Id, 16(2), 1410 4520.

Handoko, W., Iqbal, M., \& Efendi, Z. (2020). Pelatihan penerapan simulah 1.0 berbasis web bagi guru smk negeri 1 kisaran. Jurdimas (Jurnal Pengabdian Kepada Masyarakat) Royal, 3(2), 135-140.

Fahmi, M. I., Kifti, W. M., \& Marpaung, N. (2020). Pemanfaatan Teknologi Informasi Dalam
Penggunaan Website Sebagai Media Informasi Pada Polsek Porsea Kabupaten Toba Samosir. Jurdimas (Jurnal Pengabdian Kepada Masyarakat) Royal, 3(1), 51-54.

Novansyah, A., Sunardi, H., \& Ramadhan, M. (2015). Sistem Informasi Pengolahan Zakat dan Infaq pada Masjid Agung Palembang. Jurnal Informatika Global, 6(1), 15-20. 